\begin{tabular}{|c|l|}
\hline Title & $\begin{array}{l}\text { Population genetic structure and phy logeography of masu sal mon (Oncorhynchus masou masou) inferred from } \\
\text { mitochondrial and microsatellite DNA analyses }\end{array}$ \\
\hline Author(s) & $\begin{array}{l}\text { Yu, Jeong-Nam; A zuma, Noriko; Y oon, Moongeun; Brykov, V ladimir; U rawa, Shigehiko; Nagata, Mitsuhiro; Jin, } \\
\text { Deuk-Hee; A be, Syuiti }\end{array}$ \\
\hline Citation & $\begin{array}{l}\text { Zoological science, 27(5), 375-385 } \\
\text { https://loi.org/10.2108/2s.27.375 }\end{array}$ \\
\hline Issue Date & 2010-05 \\
\hline Doc URL & http://hdl.handle.net/2115/54512 \\
\hline Type & article \\
\hline File Information & 14)Yu et al ZS.pdf \\
\hline
\end{tabular}

Instructions for use 


\section{Population Genetic Structure and Phylogeography of Masu Salmon} (Oncorhynchus Masou Masou) Inferred from Mitochondrial and Microsatellite DNA Analyses

Author(s): Jeong-Nam Yu, Noriko Azuma, Moongeun Yoon, Vladimir Brykov, Shigehiko Urawa, Mitsuhiro Nagata, Deuk-Hee Jin and Syuiti Abe

Source: Zoological Science, 27(5):375-385. 2010.

Published By: Zoological Society of Japan

DOI: $10.2108 / \mathrm{zsj} .27 .375$

URL: http://www.bioone.org/doi/full/10.2108/zsj.27.375

BioOne (www.bioone.org) is an electronic aggregator of bioscience research content, and the online home to over 160 journals and books published by not-for-profit societies, associations, museums, institutions, and presses.

Your use of this PDF, the BioOne Web site, and all posted and associated content indicates your acceptance of BioOne's Terms of Use, available at www.bioone.org/page/terms_of_use.

Usage of BioOne content is strictly limited to personal, educational, and non-commercial use. Commercial inquiries or rights and permissions requests should be directed to the individual publisher as copyright holder. 


\title{
Population Genetic Structure and Phylogeography of Masu Salmon (Oncorhynchus masou masou) Inferred from Mitochondrial and Microsatellite DNA Analyses
}

\author{
Jeong-Nam Yu ${ }^{1}$, Noriko Azuma ${ }^{1}$, Moongeun Yoon ${ }^{5}$, Vladimir Brykov' ${ }^{2}$, \\ Shigehiko Urawa ${ }^{3}$, Mitsuhiro Nagata ${ }^{4}$, Deuk-Hee $\mathrm{Jin}^{5}$ \\ and Syuiti Abe ${ }^{1 *}$ \\ ${ }^{1}$ Division of Marine Biociences, Graduate School of Fisheries Sciences, Hokkaido University, \\ Hakodate 041-8611, Japan \\ ${ }^{2}$ Institute of Marine Biology, Far East Branch of Russian Academy of Science, Vladivostok 690950, Russia \\ ${ }^{3}$ Gene Conservation Section, National Salmon Resources Center, Fisheries Research Agency, \\ 2-2 Nakanoshima, Toyohira-ku, Sapporo 062-0922, Japan \\ ${ }^{4}$ Hokkaido Fish Hatchery, Eniwa, Hokkaido 061-1433, Japan \\ ${ }^{5}$ Faculty of Marine Bioscience \& Technology, Kangnung National University, \\ Gangneung 210-702, Korea
}

\begin{abstract}
The population genetic structure and phylogeography of masu salmon were investigated by using variation in the mitochondrial NADH dehydrogenase subunit 5 gene (ND5) and six polymorphic microsatellite loci among a total of 895 fish representing 18 populations collected from Japan (9), Russia (7), and Korea (2) from 2000 to 2008. An analysis of ND5 nucleotide sequences revealed 22 variable sites in about $560 \mathrm{bp}$ in the $5^{\prime}$ half of the gene, which defined 20 haplotypes, including some associated with geographical regions. Haplotype and nucleotide diversities were greater in the populations in Japan and Korea than in those in Russia, indicating greater genetic diversity in the Japanese and Korean populations than in the Russian populations. All the microsatellite loci examined showed a high level of variation, but the expected heterozygosity indicated a similar level of genetic diversity among the populations of the three regions, contrary to the results for ND5. However, AMOVA and pairwise population $F_{\mathrm{ST}}$ estimates for both ND5 and the microsatellite markers indicated a similar pattern of moderate genetic differentiation among populations of the three regions, and large population groups on the coasts of the Sea of Japan, Sea of Okhotsk, and Pacific Ocean in the Far East. From a mismatch distribution analysis and neutrality test, the observed genetic structure appears to have been influenced primarily by bottlenecks during glacial periods and population expansions during interglacial periods in the late Pleistocene.
\end{abstract}

Key words: genetic variation, masu salmon, microsatellite, mitochondrial ND5, phylogeography, population structure

\section{INTRODUCTION}

Masu salmon, Oncorhynchus masou masou (Brevoort), is endemic to the Far East, ranging from the southwestern Kamchatka Peninsula southward to Sakhalin, Hokkaido, and western Honshu, and extends from the Primorye region to the Korean Peninsula (Kato, 1991). Masu salmon has a diverse life history, with both river-resident and anadromous forms (Kato, 1991). Spawning adults, like other Pacific salmons, home to the natal river, with the rare occurrence of strays into non-natal rivers (Kato, 1991), which leads to

\footnotetext{
* Corresponding author. Phone: +81-138-40-8864; Fax : +81-138-40-8864;

E-mail: abesyu@ @ish.hokudai.ac.jp

Supplemental material for this article is available online at http://dx.doi.org/10.2108/zsj.27.375.s1. doi:10.2108/zsj.27.375
}

partial genetic differentiation among river populations.

Although masu salmon is an important fisheries species, its commercial catch has decreased over the years (Miyakoshi et al., 2001, 2004). Hatchery programs have been established to release fry artificially obtained from eggs of the limited spawning groups, which will cause decreased genetic diversity of subsequent breeding groups, possibly affecting the genetic structure of natural breeding groups (Noguchi and Taniguchi, 2007). Genetic diversity is important for the long-term survival of natural populations, because it confers the ability to adapt to changing environmental conditions, thereby increasing their fitness (Frankel and Soule, 1981; Hoffmann and Sgrb, 1995). Genetic variation must be characterized in both wild and cultured masu salmon populations to effectively manage and conserve diversity. In this regard, molecular genetic markers may be used to help identify lines or strains, define 
stock diversity, monitor inbreeding, diagnose simply inherited traits, and even improve stocks through markerassisted selection (Taniguchi et al., 1996; Davis and Hetzel, 2000). The population structure of masu salmon has so far been characterized with a few genetic studies using polymorphic allozymes (Okazaki, 1986) and mitochondrial DNA analyses relying on restriction fragment length polymorphism (RFLP) (Kijima and Matsunami, 1992; Suzuki et al., 2000) and nucleotide sequence variation (Edpalina et al. 2004; Kitanishi et al. 2007). However, molecular population genetic studies have not been conducted widely in the natural range of masu salmon in the Far East.

Kitanishi et al. (2007) found substantial variation in nucleotide sequences of a region of the mitochondrial NADH dehydrogenase subunit 5 gene (ND5) in masu salmon fry collected from Hokkaido Island, Japan. Their findings indicate a high potential for mitochondrial DNA sequence analysis in estimating genetic variation in masu salmon populations. Because of its rapid evolutionary rate compared to nuclear DNA, mitochondrial DNA allows the magnified examination of matrilineal differences among genetically discrete populations. However, males and females of a species may differ in the mechanisms of or behavior related to dispersal. Thus, population structures estimated with maternally inherited mitochondrial DNA alone may differ from that assessed with biparentally inherited nuclear DNA markers, such as microsatellites (ms). Microsatellites can effectively reveal extensive allelic variation and high levels of variability (O'Connell and Wright, 1997), allowing the detection of differences even among closely related populations. In addition, both mitochondrial and microsatellite DNA require relatively few samples for estimating variation and do not require lethal sampling.

In this study, we analyzed genetic variation and population structure in masu salmon by analyzing ND5 sequences and polymorphic microsatellite loci in nearly 900 homing fish from 18 populations in Japan, Russia, and Korea. We also examined the historical demography of masu salmon to aid in biodiversity conservation and stock management.

\section{MATERIAL AND METHODS}

\section{Fish sampling and DNA extraction}

Liver or adipose fin from 895 masu salmon representing 18 river populations in Japan (seven in Hokkaido and two in Honshu), Russia (one in Primorye, one in Kamchatka, and five in Sakhalin) and Korea (two) were collected from 2000 to 2008 (Fig. 1; Table 1). All tissue samples were fixed in ethanol and stored at room temperature until DNA extraction. Total genomic DNA was extracted from ethanol-fixed tissues with a Gentra Puregene Tissue Kit (QIAGEN) following the manufacturer's protocol. Extracted DNA was dissolved in TE buffer (10 mM Tris-HCl, 1 mM EDTA, $\mathrm{pH}$ 7.3), subjected to electrophoresis in $1 \%$ agarose gel, and stained in ethidium bromide to check the size and quality.

\section{ND5 analysis}

About 560 bp of the 5 ' half of ND5 were amplified with primer pair ND5-1F and ND5-3R (Kitanishi et al., 2007). Novel reverse primers ND5-R1 (R-AGAATGAGGCCCATAAGAGG) and ND5-R2 (R-TAGGCTCCCGATTGTGAGAC), were designed for direct nucleotide sequencing.

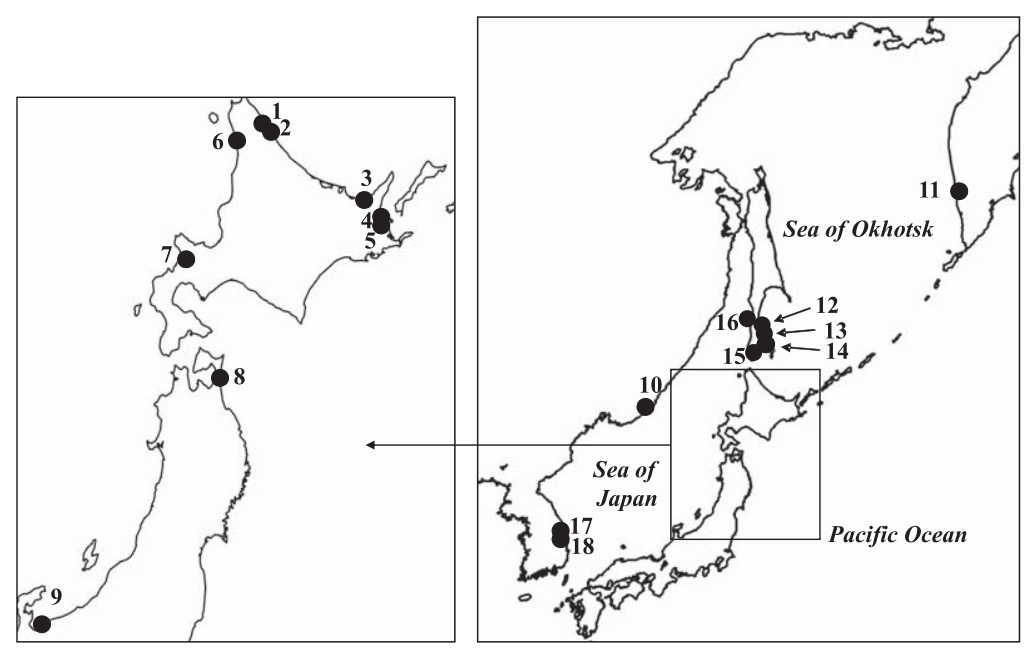

Fig. 1. Map of Japan, Korea, and eastern Russia showing the river locations where masu salmon (Oncorhynchus masou masou) were sampled. Sampling locations: Japan: 1, Kitami-horobetsu; 2, Tokushibetsu; 3, Shari; 4, Ichani; 5, Shibetsu; 6 , Teshio; 7, Shiribetsu; 8, Oippe; and 9, Jinzu. Russia: 10, Taezanaya; 11, Utka; 12, Belaya; 13, Komisarovk; 14, Sukhopletk; 15, Lutga; 16, Galuboe. Korea: 17, Namdae; 18, Wangpi.

Table 1. Information on samping sites and sampling.

\begin{tabular}{|c|c|c|c|c|c|}
\hline Sampling site & Abbreviation & Year & $\begin{array}{l}\text { Number } \\
\text { of fish }\end{array}$ & Latitude & Longitude \\
\hline \multicolumn{6}{|l|}{ Japan } \\
\hline \multicolumn{6}{|l|}{ Hokkaido } \\
\hline 1.Kitami-horobetsu & KIT & 2003 & 80 & $44^{\circ} 53^{\prime} 21.85^{\prime \prime} \mathrm{N}$ & $142^{\circ} 37^{\prime} 18.18^{\prime \prime E}$ \\
\hline 2.Tokushibetsu & TOK & 2002 & 80 & $44^{\circ} 50^{\prime} 32.20^{\prime \prime} \mathrm{N}$ & $142^{\circ} 39^{\prime} 24.91 " \mathrm{E}$ \\
\hline 3.Shari & SHA & 2001 & 78 & $43^{\circ} 54^{\prime} 55.91 " \mathrm{~N}$ & $144^{\circ} 39^{\prime} 34.02^{\prime \prime E}$ \\
\hline 4.Ichani & $\mathrm{ICH}$ & 2007 & 80 & $43^{\circ} 43^{\prime} 38.88^{\prime \prime} \mathrm{N}$ & $145^{\circ} 5^{\prime} 29.80^{\prime \prime} \mathrm{E}$ \\
\hline 5.Shibetsu & SHB & 2007 & 80 & $43^{\circ} 40^{\prime} 19.21 " \mathrm{~N}$ & $145^{\circ} 7^{\prime} 40.96 ” E$ \\
\hline 6.Teshio & TES & 2002 & 66 & $44^{\circ} 45^{\prime} 32.30^{\prime \prime} \mathrm{N}$ & $141^{\circ} 46^{\prime} 38.87^{\prime \prime} \mathrm{E}$ \\
\hline 7.Shiribetsu & $\mathrm{SHI}$ & 2000 & 78 & $43^{\circ} 1^{\prime} 17.74^{\prime \prime} \mathrm{N}$ & $140^{\circ} 31^{\prime} 52.96 ” \mathrm{E}$ \\
\hline \multicolumn{6}{|l|}{ Honshu } \\
\hline 8.Oippe & OIP & 2003 & 20 & $41^{\circ} 10^{\prime} 4.04^{\prime \prime} \mathrm{N}$ & $141^{\circ} 23^{\prime} 23.72^{\prime \prime E}$ \\
\hline 9.Jinzu & JIN & 2003 & 63 & $36^{\circ} 45^{\prime} 33.59^{\prime \prime} \mathrm{N}$ & $137^{\circ} 13^{\prime} 20.12^{\prime \prime} \mathrm{E}$ \\
\hline \multicolumn{6}{|l|}{ Russia } \\
\hline \multicolumn{6}{|l|}{ Primorye } \\
\hline 10.Taezhnaya & TAJ & 2002 & 25 & $45^{\circ} 18^{\prime} 15.05^{\prime \prime} \mathrm{N}$ & $136^{\circ} 59^{\prime} 23.21^{\prime \prime} \mathrm{E}$ \\
\hline \multicolumn{6}{|l|}{ Kamchaka } \\
\hline 11.Utka & UTK & 2002 & 20 & $53^{\circ} 26^{\prime} 49.82^{\prime \prime N}$ & $156^{\circ} 1 ' 57.87^{\prime \prime} \mathrm{E}$ \\
\hline \multicolumn{6}{|l|}{ Sakhalin } \\
\hline 12.Belaya & BEL & 2002 & 80 & $47^{\circ} 26^{\prime} 32.11^{\prime \prime} \mathrm{N}$ & $142^{\circ} 45^{\prime} 15.68^{\prime \prime} \mathrm{E}$ \\
\hline 13.Komisarovk & KOM & 2004 & 24 & $46^{\circ} 48^{\prime} 51.34^{\prime \prime} \mathrm{N}$ & $143^{\circ} 4^{\prime} 50.74^{\prime \prime} \mathrm{E}$ \\
\hline 14.Sukhopletk & SUK & 2004 & 28 & $46^{\circ} 44^{\prime} 26.46^{\prime \prime} \mathrm{N}$ & $142^{\circ} 41^{\prime} 21.72^{\prime \prime E}$ \\
\hline 15.Lutga & LUT & 2004 & 34 & $46^{\circ} 27^{\prime} 33.29^{\prime \prime} \mathrm{N}$ & $142^{\circ} 21^{\prime} 4.05^{\prime \prime} \mathrm{E}$ \\
\hline 16.Galuboe & GAL & 2004 & 19 & $47^{\circ} 58^{\prime} 45.80^{\prime \prime} \mathrm{N}$ & $142^{\circ} 12^{\prime} 8.23 " \mathrm{E}$ \\
\hline \multicolumn{6}{|l|}{ Korea } \\
\hline 17.Namdae & NAM & 2008 & 20 & $38^{\circ} 6^{\prime} 23.96^{\prime \prime} \mathrm{N}$ & $128^{\circ} 38^{\prime} 37.077^{\prime \prime E}$ \\
\hline 18.Wangpi & WAN & 2007 & 20 & $36^{\circ} 58^{\prime} 12.50^{\prime \prime} \mathrm{N}$ & $129^{\circ} 24^{\prime} 40.98^{\prime \prime} \mathrm{E}$ \\
\hline Total & & & 895 & & \\
\hline
\end{tabular}


PCR amplification was carried out in an automated thermal cycler in 20- $\mu$ l reaction volumes containing 1-2 $\mu$ l of genomic DNA, $2 \mu \mathrm{M}$ each primer, $0.25 \mathrm{mM}$ each dNTP, 1 unit of Taq DNA polymerase, and $2 \mu$ of $10 \mathrm{X}$ reaction buffer (with $1.5 \mathrm{mM} \mathrm{MgCl}_{2}$ ). The temperature profile was $5 \mathrm{~min}$ at $92^{\circ} \mathrm{C}$; 36 cycles of $95^{\circ} \mathrm{C}$ for $45 \mathrm{~s}, 56^{\circ} \mathrm{C}$ for $30 \mathrm{~s}$, and $72^{\circ} \mathrm{C}$ for $2 \mathrm{~min}$; and $72^{\circ} \mathrm{C}$ for $5 \mathrm{~min}$. After electrophoresis in $1 \%$ agarose gels, PCR products were purified with AMPure magnetic beads (Agencourt, Beverly, MA). After a sequencing reaction with an $\mathrm{ABI}$ BigDye Terminator Cycle Sequencing Ready Reaction Kit version 3.1, purified PCR products were directly sequenced on an ABI PRISM 3130XL Genetic Analyzer (Applied Biosystems).

A multiple alignment of ND5 sequences was performed with GENETIX-WIN version 4.0.1(Software Development, Japan) to identify sequence variants, from which haplotypes were defined. DNAsp 4.0 (available at http://www.ub.es/dnasp) was used to estimate nucleotide diversity $(\pi)$ and divergences between haplotypes and lineages $\left(d_{\mathrm{xy}}\right)$. The number of net nucleotide substitutions $\left(D_{\mathrm{xy}}\right)$ between haplotype lineages was computed according to Nei (1987), as $D_{\mathrm{xy}}=d_{\mathrm{xy}}-\left(d_{\mathrm{xx}}+d_{\mathrm{yy}}\right) / 2$, where $d_{\mathrm{xy}}$ is the mean nucleotide divergence between pairs of haplotypes in lineages $x$ and $y$, respectively.

\section{Microsatellite analysis}

We analyzed six microsatellite loci (Oma02, Oma03ke, Oma04my, Ots520, One111, and Omi87TUF) developed for masu salmon and other salmonids (Noguchi et al., 2003; Takayama et al., 1991; Andersson et al., 1995; Naish and Park, 2002; Olsen et al., 2000; Hara et al., unpublished data, GenBank AB213231). PCR conditions, especially annealing temperatures, were optimized for amplification of the six loci when necessary.

PCR was performed in a $10-\mu$ reaction volumes containing 0.5 $\mu$ of genomic DNA, $2 \mu \mathrm{M}$ each primer, $0.25 \mathrm{mM}$ each dNTP, 1 unit of Taq DNA polymerase, and $1 \mu \mathrm{l}$ of $10 \mathrm{X}$ reaction buffer (with 1.5 $\mathrm{mM} \mathrm{MgCl} 2$ ). The temperature profile was $5 \mathrm{~min}$ at $94^{\circ} \mathrm{C} ; 28$ cycles of $94^{\circ} \mathrm{C}$ for $40 \mathrm{~s}$, annealing (see below for temperatures) for $40 \mathrm{~s}$, and $72^{\circ} \mathrm{C}$ for $40 \mathrm{~s}$; and $72^{\circ} \mathrm{C}$ for $40 \mathrm{~min}$. The annealing temperatures used were $52^{\circ} \mathrm{C}$ for Ots520; $54^{\circ} \mathrm{C}$ for One $111 ; 56^{\circ} \mathrm{C}$ for Oma02, Oma03ke, and Oma04my; and $61^{\circ} \mathrm{C}$ for Omi87TUF. The size of fluorescence-labeled allele fragments was measured on an $A B I$ PRISM 3130XL automated sequencer, followed by analysis with GeneMapper version 3.7 (Applied Biosystems).

\section{Population genetic analyses}

To estimate the genetic variation among and within the 18 populations, haplotype diversity $(h)$, nucleotide diversity $(\pi)$, and pairwise population $F_{S T}$ values were determined by using ARLEQUIN version 3.1 (Excoffier et al., 2005). The hierarchical nesting of genetic diversity was estimated with analysis of molecular variance (AMOVA) implemented in ARLEQUIN.

A nested clade phylogeographical analysis (NCPA) using ND5 data was conducted with ANeCA v1.2 (Panchal and Beaumont, 2007), a fully automated implementation of NCPA that includes TCS v 1.21 (Clement et al., 2000) and GeoDis v2.5 (Posada et al., 2000). A nested-design cladogram was constructed at $95 \%$ parsimonious connection probability limit to infer phylogenetic relationships among ND5 haplotypes. Geographical distances within and among nested clades, clade distance $(D c)$, and nested clade distance $(D n)$ were calculated and compared among interior and tip clades, and the null hypothesis of no geographic association among haplotypes or clades at each nesting level was tested with 10,000 random permutations using GeoDis ver. 2.5. The inference key of Templeton et al. (1995) was used to infer the historical process that determined the population structure at each nesting level.

The distributions of pairwise genetic differences between individual haplotypes were analyzed with sudden expansion model (Rogers and Harpending, 1992). Goodness-of-fit tests (sum of squared deviations and Harpending's raggedness index) comparing the observed to the estimated mismatch distributions were conducted with ARLEQUIN version 2000 (Schneider et al., 2000). The timing of expansions was inferred from the mode of mismatch $(\tau)$, assuming a 3-year generation time for masu salmon. As the ND5 mutation rate was unknown for masu salmon, we estimated the time of sudden expansions by the using divergence rate of ND5 in snook (Centropomidae) (Kitanishi et al.,2007), with a range in mutation rate of $1.0-4.4 \%$ per Myr.

For the microsatellite analysis, the number of alleles per locus, expected and observed heterozygosities, departure from HardyWeinberg equilibrium (HWE), and linkage disquilibrium were calculated with GENEPOP version 3.4 (Raymond and Rousset, 2004). Allele frequencies, gene diversity, and allelic richness for each population and locus were calculated with FSTAT 2.9.3 (Goudet, 2001). Tests for the occurrence of null alleles were performed with MICRO-CHECKER 2.2.3 (Oosterhout et al., 2004). Pairwise $F_{S T}$ values and AMOVA between samples were performed with ARLEQUIN version 3.1 (Excoffier et al., 2005). In addition, genetic relationships among the populations were evaluated on a consensus tree based on Cavalli-Sforza and Edwards chord distances (1967) generated by using the Seqboot, Neighbor, and Consensus options in PHYLIP v. 3.6 (Felsenstein 2004), with a bootstrap analysis of 1000 resamplings of the loci examined.

\section{RESULTS}

\section{ND5 variation in masu salmon}

Sequence analysis of a $561 \mathrm{bp}$ fragment from the 5' half of ND5 detected 22 variable nucleotide sites among 895 individuals from 18 populations (Table 2), which defined a total of 20 haplotypes, including 10 of 13 previously reported (Kitanishi et al., 2007) and 10 newly identified, H14 to $\mathrm{H} 23$ (Table 2). Nucleotide sequences of the 10 novel haplotypes were deposited in the DDBJ/EMBL/GeneBank database under accession numbers AB469790-AB469799.

The distribution of haplotypes among 18 populations of masu salmon is given in Table 3 . The occurrence of haplotypes was different from one population to another, although haplotype $\mathrm{H} 1$ occurred in all 18 populations. Sixteen of the 20 haplotypes occurred in nine Japanese populations (625 individuals), whereas only six and seven haplotypes were found in seven Russian (230 individuals) and two Korean populations (40 individuals), respectively. Eight $(\mathrm{H} 3, \mathrm{H} 7, \mathrm{H} 13$ to $\mathrm{H} 15, \mathrm{H} 17$ to $\mathrm{H} 19)$, three $(\mathrm{H} 16, \mathrm{H} 20$, $\mathrm{H} 23)$, and one $(\mathrm{H} 8)$ haplotypes were limited to the Japanese, Russian, and Korean populations, respectively. Haplotype H3 was restricted to Japanese populations, though it was absent in the SHA population in Hokkaido, suggesting that this haplotype characterizes the Japanese populations. In addition, haplotypes $\mathrm{H} 4, \mathrm{H} 3$, and $\mathrm{H} 11$ were relatively abundant in populations from the Sea of Japan $(61 \%)$, Pacific (33\%), and the Sea of Okhotsk coasts $(81 \%)$ in Japan, respectively (Table 3 ), suggesting a regional association for these haplotypes.

The average haplotype diversity was highest in the populations in Korea (0.752), followed by those in Japan (0.535) and Russia (0.212), suggesting greater genetic variation in the Korean and Japanese populations than in those in Russia.

\section{Microsatellite variation in masu salmon}

Table 4 summarizes the number of alleles and the observed (ho) and expected heterozygosity (he) for the six 
Table 2. Variable nucleotide sites in 561-bp sequences of part of the mitochondrial ND5 gene in masu salmon.

\begin{tabular}{|c|c|c|c|c|c|c|c|c|c|c|c|c|c|c|c|c|c|c|c|c|c|c|}
\hline \multirow[b]{2}{*}{ Haplotype } & \multicolumn{22}{|c|}{ Variable nucleotide sites in 5 ' half of $N D 5$} \\
\hline & 456 & 459 & 486 & 489 & 493 & 498 & 499 & 537 & 546 & 570 & 574 & 708 & 723 & 762 & 780 & 793 & 795 & 835 & 840 & 849 & 852 & 895 \\
\hline $\mathrm{H} 1$ & $A$ & $G$ & $A$ & $\mathrm{~A}$ & $G$ & $G$ & $G$ & $\mathrm{~T}$ & $A$ & $T$ & $G$ & $C$ & $C$ & $C$ & $G$ & $C$ & $G$ & $G$ & $A$ & $C$ & $A$ & $C$ \\
\hline $\mathrm{H} 2$ & . & . & . & . & . & . & . & . & . & . & A & . & . & . & . & . & . & . & . & . & . & . \\
\hline $\mathrm{H} 3$ & . & . & . & . & . & . & . & . & $\mathrm{G}$ & . & . & . & . & . & . & . & . & . & . & . & . & . \\
\hline $\mathrm{H} 4$ & . & . & . & . & . & A & . & . & . & . & . & . & . & . & . & . & . & . & . & . & . & . \\
\hline $\mathrm{H} 7$ & . & . & . & $\mathrm{G}$ & . & . & . & . & . & . & . & . & . & . & . & . & . & . & . & . & . & . \\
\hline $\mathrm{H} 8$ & . & . & G & . & . & . & . & . & . & . & . & . & . & . & . & . & . & . & . & . & . & . \\
\hline $\mathrm{H} 10$ & . & . & . & . & . & . & . & . & $\mathrm{G}$ & . & . & . & . & $\mathrm{T}$ & . & . & . & . & . & . & . & . \\
\hline $\mathrm{H} 11$ & . & . & . & $\mathrm{G}$ & . & . & . & . & . & & . & $\mathrm{T}$ & . & . & . & . & . & . & . & . & . & . \\
\hline $\mathrm{H} 12$ & . & . & . & $G$ & . & . & . & . & . & C & . & $\mathrm{T}$ & . & . & . & $\mathrm{T}$ & . & . & . & . & . & . \\
\hline $\mathrm{H} 13$ & . & . & . & $\mathrm{G}$ & . & . & A & . & . & & . & $\mathrm{T}$ & . & . & . & & . & . & . & . & . & . \\
\hline $\mathrm{H} 14$ & $\mathrm{G}$ & . & . & . & . & . & . & . & . & . & . & . & . & . & . & . & . & . & . & . & . & . \\
\hline $\mathrm{H} 15$ & . & A & . & . & . & . & . & . & . & . & . & . & . & . & . & . & . & . & . & . & . & . \\
\hline $\mathrm{H} 16$ & . & . & . & . & A & . & . & . & . & . & . & . & . & . & . & . & . & . & . & . & . & . \\
\hline $\mathrm{H} 17$ & . & . & . & . & . & . & . & . & . & . & . & . & $\mathrm{T}$ & . & . & . & . & . & . & . & . & . \\
\hline $\mathrm{H} 18$ & . & . & . & . & . & . & . & . & . & . & . & . & . & . & . & . & A & . & . & . & . & . \\
\hline $\mathrm{H} 19$ & . & . & . & . & . & . & . & . & . & . & . & . & . & . & . & . & . & A & . & . & & . \\
\hline $\mathrm{H} 2 \mathrm{O}$ & . & . & . & . & . & . & . & . & . & . & . & . & . & . & . & . & . & . & . & . & $\mathrm{G}$ & . \\
\hline $\mathrm{H} 21$ & . & . & . & $\mathrm{G}$ & . & . & . & . & & . & . & $\mathrm{T}$ & . & . & $\mathrm{T}$ & & . & . & . & . & . & . \\
\hline $\mathrm{H} 22$ & . & . & . & . & . & . & . & C & $\mathrm{G}$ & . & . & . & . & . & . & . & . & . & $\mathrm{G}$ & . & . & . \\
\hline $\mathrm{H} 23$ & . & . & . & . & . & . & . & . & . & . & . & . & . & . & . & . & . & . & . & $\mathrm{T}$ & . & $\mathrm{T}$ \\
\hline
\end{tabular}

Table 3. Distribution of ND5 haplotypes, number of haplotypes, nucleotide diversity $(\pi)$, and haplotype diversity $(h)$ among 18 populations of masu salmon. Sampling abbreviations are listed in Table 1. Sample sizes are in parentheses.

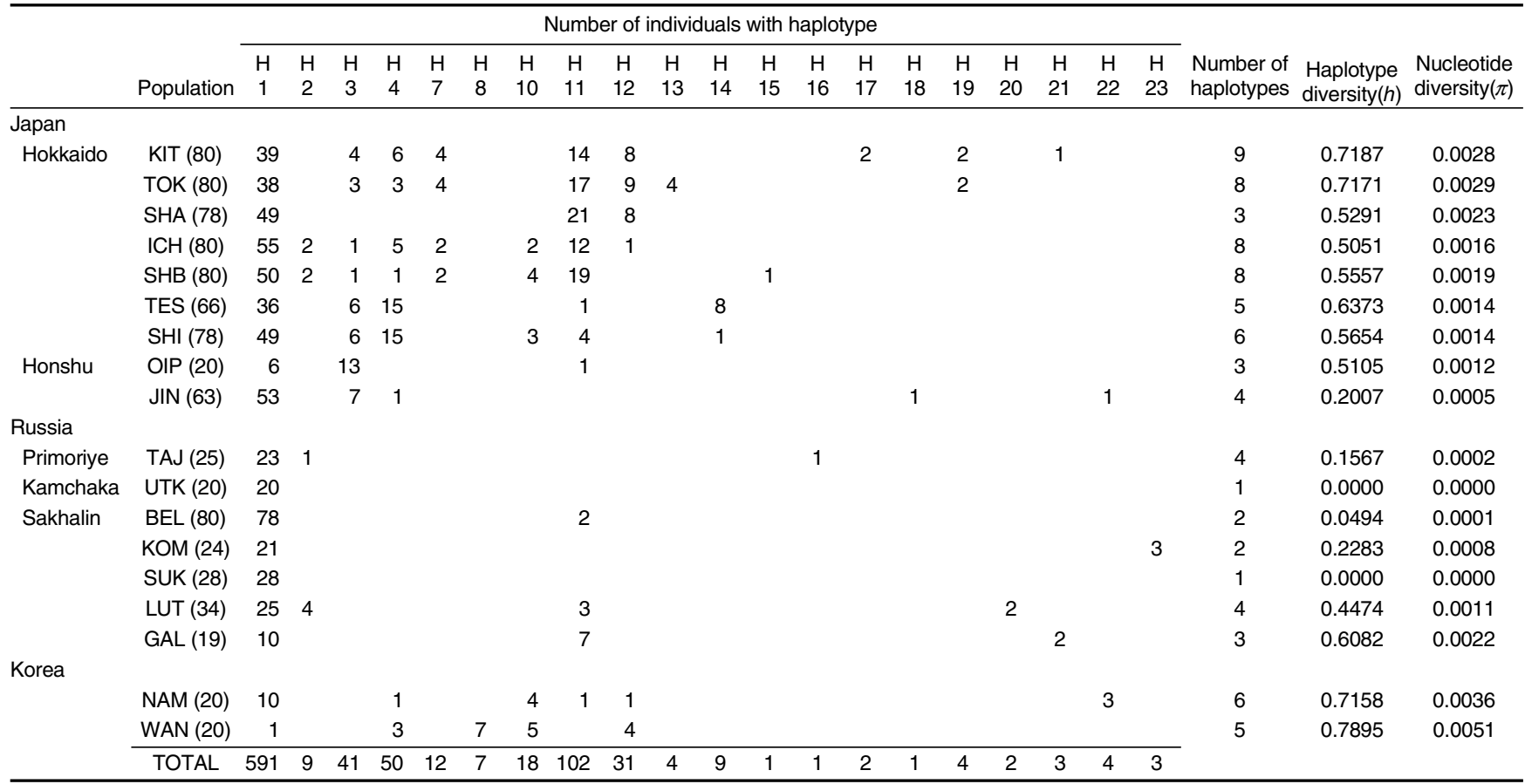

microsatellite loci. In all, 102 alleles were found among the 18 masu salmon populations examined, ranging from eight at the Oma4my locus to 29 at the Oma02 locus; these loci were originally developed for rainbow trout and masu salmon, respectively. All six loci were highly polymorphic in all populations examined, although the degree of variability was different from one locus to another. The mean allelic richness $(A r)$ among all loci within populations ranged from 6.42 (NAM) to 9.71 (TOK), and the highest (9.71 in TOK) and the lowest values (6.42 in NAM) occurring in the
Japanese and Korean populations, respectively. ho and he within populations ranged from 0.698 (JIN) to $0.817(\mathrm{ICH})$, both in Japan, and from 0.722 (NAM) in Korea to 0.814 $(\mathrm{ICH})$, respectively, with no linkage disequilibrium (Table 4). Thus, the genetic diversity estimated with he (values over $0.7)$ was similar in the populations in all three regions.

Departures from HWE were distributed among populations and loci (four populations for Oma3ke, three for Oma4my, five for Oma02, seven for Ots520, one for One111, and three for Omi87TUF) (Table 4), suggesting 
Table 4. Variation at six microsatellite loci in 18 populations of masu salmon. Sampling abbreviations are listed in Table 1. $N$, number of individuals; $N A$, number of alleles; $A r$, allelic richness; he, expected heterozygosity; ho, observed heterozygosity; $P$, estimate of probability of deviation from Hardy-Weinberg equilibrium; *, significant departure from Hardy-Weinberg equilibrium $(P<0.05)$.

\begin{tabular}{|c|c|c|c|c|c|c|c|c|c|c|c|c|c|c|c|c|c|c|c|}
\hline \multirow{2}{*}{ Loci } & \multicolumn{19}{|c|}{ Variation within each population } \\
\hline & & KIT & TOK & SHA & $\mathrm{ICH}$ & SHB & OIP & TES & SHI & JIN & TAJ & UTK & BEL & KOM & SUK & LUT & GAL & NAM & WAN \\
\hline & $N$ & 80 & 80 & 78 & 80 & 80 & 20 & 66 & 78 & 63 & 25 & 20 & 80 & 24 & 28 & 34 & 19 & 20 & 20 \\
\hline \multirow[t]{5}{*}{ Oma3ke } & $N A$ & 14 & 15 & 11 & 11 & 12 & 8 & 12 & 14 & 14 & 11 & 11 & 7 & 10 & 10 & 9 & 9 & 7 & 6 \\
\hline & $A r$ & 10.17 & 10.19 & 8.09 & 7.80 & 7.24 & 7.70 & 9.52 & 9.24 & 10.24 & 10.02 & 10.70 & 6.10 & 9.46 & 9.26 & 8.32 & 9.00 & 6.95 & 6.00 \\
\hline & he & 0.818 & 0.837 & 0.722 & 0.753 & 0.783 & 0.764 & 0.841 & 0.844 & 0.884 & 0.858 & 0.761 & 0.710 & 0.853 & 0.809 & 0.773 & 0.850 & 0.817 & 0.773 \\
\hline & ho & 0.787 & 0.800 & 0.576 & 0.775 & 0.837 & 0.809 & 0.787 & 0.833 & 0.825 & 0.920 & 0.700 & 0.737 & 0.833 & 0.892 & 0.676 & 0.894 & 0.900 & 0.950 \\
\hline & $P$ & $0.042^{\star}$ & * 0.050 & $0.000^{\star}$ & 0.513 & 0.057 & 0.492 & $0.015^{\star}$ & 0.839 & 0.310 & 0.929 & 0.237 & 0.736 & 0.655 & 0.716 & $0.011^{*}$ & 0.558 & 0.858 & 0.058 \\
\hline \multirow[t]{5}{*}{ Oma4my } & $\overline{N A}$ & 7 & 7 & 8 & 8 & 7 & 5 & 8 & 8 & 6 & 4 & 5 & 5 & 5 & 7 & 7 & 5 & 5 & 5 \\
\hline & $A r$ & 5.76 & 5.76 & 6.26 & 6.53 & 6.11 & 4.99 & 6.09 & 6.65 & 4.85 & 4.00 & 5.00 & 4.81 & 4.96 & 6.65 & 6.57 & 5.00 & 5.00 & 4.95 \\
\hline & he & 0.715 & 0.744 & 0.728 & 0.807 & 0.793 & 0.753 & 0.708 & 0.725 & 0.666 & 0.746 & 0.792 & 0.745 & 0.722 & 0.831 & 0.730 & 0.775 & 0.738 & 0.696 \\
\hline & ho & 0.587 & 0.662 & 0.705 & 0.850 & 0.787 & 0.714 & 0.606 & 0.820 & 0.619 & 0.720 & 0.750 & 0.787 & 0.708 & 0,750 & 0.617 & 0.684 & 0.600 & 0.650 \\
\hline & $P$ & $0.006^{\star}$ & * $0.007^{*}$ & 0.617 & 0.507 & 0.851 & 0.446 & 0.262 & $0.029^{*}$ & 0.233 & 0.902 & 0.065 & 0.279 & 0.890 & 0.051 & 0.477 & 0.069 & 0.415 & 0.372 \\
\hline \multirow[t]{5}{*}{ Oma02 } & $\overline{N A}$ & 23 & 26 & 19 & 21 & 19 & 15 & 18 & 24 & 19 & 11 & 11 & 20 & 11 & 14 & 20 & 11 & 7 & 8 \\
\hline & $A r$ & 10.49 & 12.81 & 9.91 & 11.83 & 10.67 & 9.80 & 11.72 & 12.12 & 11.09 & 10.29 & 9.75 & 10.40 & 10.29 & 10.84 & 11.80 & 12.00 & 7.00 & 7.80 \\
\hline & he & 0.929 & 0.940 & 0.918 & 0.912 & 0.861 & 0.873 & 0.861 & 0.844 & 0.905 & 0.873 & 0.841 & 0.907 & 0.840 & 0.874 & 0.922 & 0.836 & 0.652 & 0.767 \\
\hline & ho & 0.800 & 0.912 & 0.884 & 0.875 & 0.700 & 0.904 & 0.818 & 0.833 & 0.714 & 0.800 & 0.900 & 0.862 & 0.750 & 0.892 & 0.764 & 0.842 & 0.750 & 0.650 \\
\hline & $P$ & $0.004^{\star}$ & * 0.298 & 0.323 & 0.238 & $0.002^{*}$ & 0.885 & $0.008^{*}$ & 0.839 & $0.000^{*}$ & 0.442 & 0.613 & 0.647 & 0.119 & 0.197 & $0.002^{*}$ & 0.112 & 0.298 & 0.730 \\
\hline \multirow[t]{5}{*}{ Ots520 } & $N A$ & 13 & 15 & 14 & 14 & 12 & 10 & 14 & 15 & 15 & 11 & 10 & 13 & 11 & 12 & 13 & 12 & 10 & 9 \\
\hline & $A r$ & 10.49 & 12.81 & 9.91 & 11.83 & 10.67 & 9.80 & 11.72 & 12.12 & 11.09 & 10.29 & 9.75 & 10.40 & 10.29 & 10.84 & 11.80 & 12.00 & 9.90 & 9.00 \\
\hline & he & 0.877 & 0.911 & 0.831 & 0.895 & 0.869 & 0.860 & 0.885 & 0.881 & 0.864 & 0.846 & 0.833 & 0.890 & 0.869 & 0.873 & 0.902 & 0.886 & 0.893 & 0.866 \\
\hline & ho & 0.862 & 0.862 & 0.692 & 0.812 & 0.675 & 0.714 & 0.818 & 0.730 & 0.809 & 0.760 & 0.750 & 0.737 & 0.583 & 0.857 & 0.764 & 0.736 & 1.000 & 0.850 \\
\hline & $P$ & 0.054 & $0.017^{\star}$ & 0.138 & $0.000^{*}$ & $0.000^{*}$ & 0.297 & 0.157 & $0.000^{*}$ & 0.252 & 0.260 & 0.397 & $0.000^{*}$ & * $0.000^{*}$ & 0.890 & $0.009^{*}$ & 0.115 & 0.927 & 0.093 \\
\hline \multirow[t]{5}{*}{ One111 } & $N A$ & 5 & 6 & 5 & 6 & 4 & 3 & 5 & 5 & 4 & 5 & 3 & 5 & 4 & 4 & 5 & 3 & 4 & 7 \\
\hline & $A r$ & 4.13 & 4.70 & 3.49 & 4.45 & 3.24 & 3.00 & 4.53 & 4.00 & 3.93 & 4.71 & 3.00 & 3.66 & 3.96 & 3.68 & 4.37 & 3.00 & 3.95 & 6.90 \\
\hline & he & 0.670 & 0.648 & 0.642 & 0.661 & 0.627 & 0.528 & 0.412 & 0.443 & 0.680 & 0.635 & 0.447 & 0.645 & 0.605 & 0.622 & 0.622 & 0.631 & 0.480 & 0.679 \\
\hline & ho & 0.650 & 0.650 & 0.730 & 0.837 & 0.700 & 0.476 & 0.409 & 0.461 & 0.650 & 0.760 & 0.550 & 0.712 & 0.666 & 0.607 & 0.705 & 0.473 & 0.500 & 0.800 \\
\hline & $P$ & 0.321 & 0.973 & 0.309 & $0.000^{*}$ & 0.259 & 0.286 & 0.389 & 0.452 & 0.868 & 0.178 & 0.777 & 0.133 & 0.833 & 0.734 & 0.440 & 0.211 & 0.483 & 0.192 \\
\hline \multirow[t]{5}{*}{ Omi87TUF } & $N A$ & 12 & 10 & 9 & 12 & 9 & 8 & 11 & 11 & 10 & 8 & 7 & 11 & 7 & 5 & 8 & 6 & 6 & 9 \\
\hline & $A r$ & 9.31 & 7.43 & 7.24 & 8.92 & 7.83 & 6.90 & 8.81 & 8.17 & 8.40 & 7.46 & 6.90 & 8.38 & 6.78 & 5.00 & 7.15 & 6.00 & 5.95 & 8.85 \\
\hline & he & 0.856 & 0.767 & 0.771 & 0.853 & 0.824 & 0.803 & 0.840 & 0.846 & 0.789 & 0.802 & 0.666 & 0.784 & 0.826 & 0.708 & 0.794 & 0.736 & 0.751 & 0.825 \\
\hline & ho & 0.875 & 0.712 & 0.692 & 0.750 & 0.837 & 0.666 & 0.909 & 0.897 & 0.571 & 0.800 & 0.550 & 0.675 & 0.750 & 0.714 & 0.823 & 0.789 & 0.850 & 0.900 \\
\hline & $P$ & 0.493 & 0.426 & 0.553 & 0.069 & 0.766 & 0.259 & $0.030^{*}$ & 0.133 & $0.000^{*}$ & 0.519 & $0.013^{*}$ & 0.106 & 0.591 & 0.862 & 0.495 & 0.885 & 0.667 & 0.192 \\
\hline \multirow[t]{4}{*}{ Mean } & $\overline{N A}$ & 12.33 & 13.17 & 11.00 & 12.00 & 10.50 & 8.00 & 11.33 & 12.67 & 11.33 & 8.33 & $\begin{array}{l}7.83 \\
\end{array}$ & 10.17 & 8.00 & 8.67 & 10.33 & 7.67 & 6.50 & 7.33 \\
\hline & $A r$ & 9.33 & 9.71 & 8.12 & 9.02 & 8.07 & 7.77 & 8.82 & 9.07 & 8.73 & 7.88 & 7.67 & 7.90 & 7.64 & 7.90 & 8.96 & 7.67 & 6.42 & 7.23 \\
\hline & he & 0.811 & 0.808 & 0.769 & 0.814 & 0.793 & 0.764 & 0.758 & 0.767 & 0.798 & 0.793 & 0.723 & 0.780 & 0.786 & 0.786 & 0.791 & 0.786 & 0.722 & 0.768 \\
\hline & ho & 0.760 & 0.766 & 0.713 & 0.817 & 0.756 & 0.714 & 0.725 & 0.765 & 0.698 & 0.793 & 0.700 & 0.752 & 0.715 & 0.792 & 0.725 & 0.736 & 0.766 & 0.800 \\
\hline
\end{tabular}

possible null alleles at these loci, as determined wiht MICRO-CHECKER.

\section{Population genetic structure estimated from ND5 and microsatellites}

Pairwise population $F_{\mathrm{ST}}$ estimates in masu salmon based on both ND5 and microsatellites are given in Table 5 . Although the $F_{\mathrm{ST}}$ estimates did not necessarily show clear genetic differentiation within and among regions, there appeared to be distinct in both markers between OIP (Pacific coast) and most populations on the Sea of Okhotsk or Sea of Japan coasts in all regions. Substantial differentiation in ND5 appeared to exist between TES from the Sea of Japan and most populations from coasts of the Sea of Okhotsk in Japan. Similarly, differentiation was apparent between GAL (west coast of Sakhalin) and most other populations from coasts of the Sea of Japan or Pacific in all other regions. Microsatellite differentiation appeared to exist between UTK from the west coast of Kamchatka and other populations in all regions. A similar level of microsatellite differentiation was also evident between two populations in Korea (NAM and WAN) and most others in all regions.

The consensus $\mathrm{NJ}$ tree from the microsatellite data, however, showed a population cluster with nodal bootstrap values mostly less than $50 \%$, and thus did not distinguish geographical groups among the populations examined (see Supplemental Fig. S1 online).

AMOVA with both markers (Table 6) revealed the following population structure in masu salmon: (i) significant geographic structuring among Japan, Russia, and Korea (ND5, 4.54\%, $P<0.05$; microsatellites, 1.65\%, $P<0.001$; Analysis I); (ii) significant geographic structuring among the coasts of the Sea of Japan, Pacific, and Sea of Okhotsk in all regions (ND5, 6.12\%, $P<0.05$; microsatellites, $2.07 \%, P$ $<0.001$; Analysis II); (iii) significant geographic structuring among the coasts of the Sea of Japan, Sea of Okhotsk, and Pacific in Japan (ND5, 15.14\%, $P<0.005$; microsatellites, $2.63 \%, P<0.005$; Analysis III), but not significant among Primorye, Sakhalin, and Kamchatka in Russia (ND5, -20.55, $P>0.05$; microsatellites, $1.86 \%, P>0.05$ ) (not shown); (iv) significant geographic structuring between two coastal 
Table 5. Pairwise $F_{\mathrm{ST}}$ estimates among masu salmon populations in all regions. The statistical significance of $F_{\mathrm{ST}}$ values was tested with the exact test after sequential Bonferroni adjustments $\left({ }^{\star}, P<0.05 ;{ }^{\star *} ; P<0.001\right)$. Sampling abbreviations are listed in Table $1 . F_{\mathrm{ST}}$ values $>0.05$ (below diagonal, microsatellites) and $F_{\mathrm{ST}}$ values $>0.15$ (above diagonal, ND5) are in bold font. The gray background denotes $F_{\mathrm{ST}}$ values $>$ 0.07 (below diagonal, microsatellites) and $F_{\mathrm{ST}}$ values $>0.2$ (above diagonal, ND5).

\begin{tabular}{|c|c|c|c|c|c|c|c|c|c|c|c|c|c|c|c|c|c|c|}
\hline & KIT & TOK & SHA & $\mathrm{ICH}$ & SHB & OIP & TES & $\mathrm{SHI}$ & JIN & TAJ & UTK & BEL & KOM & SUK & LUT & GAL & NAM & WAN \\
\hline KIT & & 0.000 & 0.000 & $0.032^{*}$ & 0.015 & $0.254^{\star \star}$ & $0.152^{\star \star}$ & $0.119^{\star *}$ & $0.157^{\star \star}$ & $0.135^{\star *}$ & $0.127^{\star \star}$ & $0.180^{\star *}$ & $0.142^{*}$ & $0.143^{\star *}$ & $0.084^{\star \star}$ & 0.026 & $0.116^{\star}$ & $0.107^{\star \star}$ \\
\hline TOK & $0.008^{\star \star}$ & & -0.007 & $0.079^{\star \star}$ & $0.043^{*}$ & $0.291^{\star \star *}$ & $0.221^{\star \star *}$ & $0.188^{\star \star}$ & $0.224^{\star \star}$ & $0.196^{\star \star}$ & $0.188^{\star *}$ & $0.255^{\star \star}$ & $0.199^{\star \star}$ & $0.206^{\star \star}$ & $0.136^{\star \star}$ & 0.002 & $0.156^{\star \star}$ & $0.130^{\star *}$ \\
\hline SHA & $0.031^{\star *}$ & $0.023^{\star *}$ & & $0.072^{\star *}$ & 0.035 & $0.340^{\star *}$ & $0.236^{\star \star *}$ & $0.198^{\star \star}$ & $0.237^{\star \star}$ & $0.207^{\star \star}$ & $0.200^{\star *}$ & $0.265^{\star \star}$ & $0.210^{\star *}$ & $0.219^{\star \star *}$ & 0.136 & 0.008 & $0.178^{\star \star}$ & $0.154^{\star \star}$ \\
\hline $\mathrm{ICH}$ & $0.015^{\star \star}$ & $0.016^{\star *}$ & $0.026^{\star \star}$ & & 0.004 & $0.318^{\star \star}$ & $0.093^{\star \star}$ & $0.051^{\star \star}$ & $0.082^{\star \star}$ & $0.064^{*}$ & $0.058^{\star}$ & $0.083^{\star \star}$ & $0.088^{*}$ & $0.071^{\star}$ & 0.018 & $0.145^{\star \star}$ & $0.126^{\star}$ & $0.170^{\star \star}$ \\
\hline SHB & $0.020^{* *}$ & $0.023^{\star *}$ & $0.029^{\star *}$ & $0.006^{\star *}$ & & $0.285^{\star \star}$ & $0.246^{\star \star}$ & $0.098^{\star *}$ & $0.130^{\star *}$ & $0.115^{\star \star}$ & $0.109^{*}$ & $0.148^{\star *}$ & $0.129^{\star *}$ & $0.124^{\star *}$ & $0.051^{\star *}$ & $0.070^{*}$ & $0.115^{\star \star}$ & $0.153^{\star \star}$ \\
\hline OIP & $0.070^{* *}$ & $0.073^{\star *}$ & $0.110^{* *}$ & $0.067^{\star *}$ & $0.067^{\star *}$ & & $0.315^{\star \star}$ & $0.275^{\star}$ & $0.396^{* *}$ & $0.515^{\star \star}$ & $0.547^{\star *}$ & $0.664^{\star *}$ & $0.437^{* *}$ & $0.597^{\star *}$ & $0.384^{\star *}$ & $0.437^{\star \star *}$ & $0.081^{*}$ & $0.185^{\star \star}$ \\
\hline TES & $0.041^{\star \star}$ & $0.044^{\star \star}$ & $0.074^{\star \star}$ & $0.052^{\star \star}$ & $0.047^{\star \star}$ & $0.082^{\star \star}$ & & 0.007 & $0.089^{\star \star}$ & $0.088^{*}$ & $0.081^{*}$ & $0.142^{\star \star}$ & $0.108^{\star \star}$ & $0.097^{\star}$ & $0.102^{\star \star}$ & $0.346^{\star \star}$ & $0.144^{\star \star}$ & $0.210^{\star \star *}$ \\
\hline JIN & $0.035^{\star \star}$ & $0.030^{\star \star}$ & $0.071^{\star \star}$ & $0.049^{\star \star}$ & $0.054^{\star \star}$ & $0.066^{\star \star}$ & $0.049^{\star \star}$ & $0.042^{\star \star}$ & & 0.018 & 0.007 & $0.040^{*}$ & $0.078^{\star \star}$ & 0.019 & $0.064^{\star \star}$ & $0.445^{\star \star}$ & $0.152^{\star \star}$ & $0.277^{\star *}$ \\
\hline TAJ & $0.037^{\star *}$ & $0.035^{\star *}$ & $0.045^{\star *}$ & $0.021^{* *}$ & $0.014^{\star *}$ & $0.082^{\star \star}$ & $0.055^{\star *}$ & $0.041^{* *}$ & $0.048^{\star *}$ & & -0.009 & 0.013 & 0.067 & 0.005 & 0.024 & $0.409^{\star \star}$ & $0.164^{\star \star}$ & $0.214^{\star *}$ \\
\hline UTK & $0.085^{\star *}$ & $0.078^{\star *}$ & $0.077^{\star *}$ & $0.073^{\star \star}$ & $0.086^{\star \star}$ & $0.096^{\star \star}$ & 0.15 & $0.128^{\star \star}$ & $0.101^{\star *}$ & $0.094^{\star \star}$ & & -0.016 & 0.073 & 0.000 & 0.037 & $0.413^{\star \star}$ & $0.154^{\star \star}$ & $0.199^{\star *}$ \\
\hline BEL & $0.042^{\star *}$ & $0.029^{\star *}$ & $0.038^{\star \star}$ & $0.020^{\star \star}$ & $0.026^{\star \star}$ & $0.091^{\star *}$ & $0.076^{\star \star}$ & $0.060^{\star \star}$ & $0.065^{\star \star}$ & $0.032^{\star \star}$ & $0.066^{\star \star}$ & & $0.136^{*}$ & -0.007 & $0.070^{\star \star}$ & $0.563^{\star \star}$ & $0.309^{\star \star}$ & $0.380^{* *}$ \\
\hline KOM & $0.034^{\star *}$ & $0.028^{\star *}$ & $0.059^{\star \star}$ & $0.038^{\star *}$ & $0.039^{\star *}$ & $0.087^{\star \star \star}$ & $0.057^{\star \star}$ & $0.048^{\star *}$ & $0.045^{\star \star}$ & $0.053^{\star \star}$ & $0.085^{\star \star}$ & $0.060^{\star *}$ & & 0.099 & $0.070^{\star \star}$ & $0.360^{\star \star \star}$ & $0.154^{\star \star}$ & $0.200^{* *}$ \\
\hline SUK & $0.054^{\star \star}$ & $0.038^{\star *}$ & $0.046^{\star *}$ & $0.026^{\star *}$ & $0.023^{\star *}$ & $0.060^{\star \star}$ & $0.082^{\star \star}$ & $0.065^{\star \star}$ & $0.062^{\star \star}$ & $0.028^{\star *}$ & $0.053^{\star \star}$ & $0.019^{\star *}$ & $0.053^{\star \star}$ & & $0.055^{\star}$ & $0.467^{\star \star}$ & $0.192^{\star \star}$ & $0.241^{\star *}$ \\
\hline LUT & $0.032^{\star *}$ & $0.017^{\star *}$ & $0.025^{\star *}$ & $0.020^{\star *}$ & $0.026^{\star \star}$ & $0.087^{\star \star *}$ & $0.063^{\star \star}$ & $0.048^{\star *}$ & $0.052^{\star \star}$ & $0.035^{\star *}$ & $0.059^{\star *}$ & $0.023^{\star *}$ & $0.042^{\star *}$ & $0.024^{\star *}$ & & $0.250^{\star \star \star}$ & $0.138^{\star *}$ & $0.185^{\star \star}$ \\
\hline NAM & $0.089^{* *}$ & $0.081^{* *}$ & $0.108^{\star *}$ & $0.086^{\star *}$ & $0.071^{\star *}$ & $0.141^{\star *}$ & $0.055^{\star \star}$ & $0.058^{\star *}$ & $0.094^{\star *}$ & $0.067^{\star \star}$ & $0.210^{\star *}$ & $0.109^{* *}$ & $0.094^{\star *}$ & $0.096^{\star *}$ & $0.097^{\star *}$ & $0.102^{\star *}$ & & 0.051 \\
\hline WAN & $0.075^{\star *}$ & $0.078^{\star *}$ & $0.094^{\star *}$ & $0.080^{\star *}$ & $0.070^{\star *}$ & $0.122^{\star \star}$ & $0.058^{\star \star}$ & $0.053^{\star \star}$ & $0.072^{\star \star}$ & 0.069 ** & $0.168^{\star *}$ & $0.102^{\star \star}$ & $0.070^{\star *}$ & $0.099^{\star *}$ & $0.088^{\star *}$ & $0.095^{\star *}$ & $0.046^{\star \star}$ & \\
\hline
\end{tabular}

Table 6. Analysis of molecular variance (AMOVA) among three levels of the population hierarchy for ND5 and microsatellite markers.

\begin{tabular}{|c|c|c|c|c|c|c|}
\hline \multirow{2}{*}{ Hierarchical structure } & \multicolumn{3}{|c|}{ ND5 } & \multicolumn{3}{|c|}{ Microsatellites } \\
\hline & $\%$ & $\Phi$ & $P$ & $\%$ & $\Phi$ & $P$ \\
\hline \multicolumn{7}{|l|}{ Analysis I } \\
\hline $\begin{array}{l}\text { Among three regional groups } \\
\text { (Japan, Russia and Korea) }\end{array}$ & 4.54 & 0.045 & $<0.05$ & 1.65 & 0.016 & $<0.001$ \\
\hline Among populations within group & 11.43 & 0.119 & $<0.001$ & 3.80 & 0.039 & $<0.001$ \\
\hline Within population & 84.02 & 0.159 & $<0.001$ & 94.55 & 0.054 & $<0.001$ \\
\hline \multicolumn{7}{|l|}{ Analysis II } \\
\hline $\begin{array}{l}\text { Among three geographical groups } \\
\text { (Sea of Japan coast, Sea of Okhotsk } \\
\text { coasts and Pacific Ocean coasts) }\end{array}$ & 6.12 & 0.061 & $<0.05$ & 2.07 & 0.021 & $<0.001$ \\
\hline Among populations within group & 10.43 & 0.111 & $<0.001$ & 3.54 & 0.036 & $<0.001$ \\
\hline Within populations & 83.45 & 0.165 & $<0.001$ & 94.40 & 0.056 & $<0.001$ \\
\hline \multicolumn{7}{|l|}{ Analysis III } \\
\hline $\begin{array}{l}\text { Among three regional groups in Japan } \\
\text { (Sea of Japan coasts, Sea of Okhotsk } \\
\text { coasts and Pacific Ocean coasts) }\end{array}$ & 15.14 & 0.151 & $<0.005$ & 2.63 & 0.026 & $<0.005$ \\
\hline Among populations within group & 2.66 & 0.031 & $<0.001$ & 2.28 & 0.023 & $<0.001$ \\
\hline \multicolumn{7}{|l|}{ Analysis IV } \\
\hline $\begin{array}{l}\text { Between two regional groups } \\
\text { (Japan and Russian coasts in } \\
\text { the Sea of Okhotsk) }\end{array}$ & 13.41 & 0.134 & $<0.01$ & 0.82 & 0.008 & $<0.01$ \\
\hline Among populations within group & 2.27 & 0.026 & $<0.005$ & 2.62 & 0.026 & $<0.001$ \\
\hline Within population & 84.32 & 0.157 & $<0.001$ & 96.57 & 0.034 & $<0.001$ \\
\hline \multicolumn{7}{|l|}{ Analysis V } \\
\hline $\begin{array}{l}\text { Among three regional groups } \\
\text { (Japan, Russia and Korea coasts } \\
\text { in the Sea of Japan) }\end{array}$ & 8.87 & 0.089 & $<0.01$ & 2.61 & 0.026 & $<0.05$ \\
\hline Among populations within groups & 8.85 & 0.097 & $<0.001$ & 3.35 & 0.034 & $<0.001$ \\
\hline Within populations & 82.28 & 0.177 & $<0.001$ & 94.03 & 0.060 & $<0.001$ \\
\hline
\end{tabular}

Table 7. Average values for nucleotide diversity $(\pi)$, nucleotide divergence $(d x y)$, and net nucleotide divergence $(D x y)$ within and between clades. $n$, number of haplotypes in each clade.

\begin{tabular}{lccc}
\hline & $\begin{array}{c}\text { Nucleotide } \\
\text { diversity } \\
(\pi)\end{array}$ & $\begin{array}{c}\text { Nucleotide } \\
\text { divergence } \\
(d x y)\end{array}$ & $\begin{array}{c}\text { Net Nucleotide } \\
\text { divergence } \\
(D \text { xy })\end{array}$ \\
\hline Clade2-1 $(n=12)$ & 0.00327 & 0.00300 & -0.00027 \\
Clade2-2 $(n=5)$ & 0.00357 & 0.00285 & -0.00071 \\
Clade2-3 $(n=3)$ & 0.00357 & 0.00238 & -0.00119 \\
Clade 2-1 and 2-2 & 0.00461 & 0.00627 & 0.00285 \\
Clade 2-1 and 2-3 & 0.00394 & 0.00520 & 0.00178 \\
Clade 2-2 and 2-3 & 0.00605 & 0.00820 & 0.00463 \\
\hline
\end{tabular}

congruence of both mitochondrial and microsatellite markers in estimating the genetic structure of masu salmon, suggesting the existence of three large population groups in addition to previous geographical groupings of masu salmon into populations in Japan, Russia, and Korea.

\section{Historical demography of masu salmon}

The nested $95 \%$ set of plausible cladograms for the observed 20 ND5 haplotypes was constructed with NCPA (Fig. 2); a focal haplotype (H1) and derived haplotypes showed a clear star-like genealogy. The observed ND5 haplotypes were separated into six 1-step clades (1-1, 1-2, 1-3, 1-4, $1-5$, and 1-6) and three 2-step clades (2-1, 2-2 and $2-3)$; the last group included all haplotypes in a single 3-step clade (Fig. 3). The average number of nucleotide substitutions per site and the nucleotide diversity between and within clades are presented in

regions in the Sea of Okhotsk (ND5, 13.41\%, $P<0.01$; microsatellites, $0.82 \%, P<0.01$; Analysis IV); (v) significant geographic structuring among three coastal regions in Sea of Japan (ND5, 8.87\%, $P<0.01$; microsatellites, $2.61 \%, P$ $<0.05$; Analysis V). The results obtained thus indicated
Table 7. Estimates of both parameters were less than 0.01 in all cases, indicating a rather shallow genealogy for ND5 haplotypes in masu salmon.

Fig. 3 presents the results of the nested clades analysis of geographical distances. Mapping the distribution of the 
major 2-step clades in Fig. 3 revealed that clade 2-1 was spread among most populations, clade 2-2 comprised most of the Sea of Japan and Pacific (although only one population), and clade 2-3 comprised most of the Sea of Okhotsk populations. The interpretation of these statistical results (Fig. 3; Table 8), employing the latest inference key from Templeton et al. (1995), was restricted gene flow with isolation by distance (IBD) for clade 2-1, and contiguous range expansion (CRE) for clades 2-2 and 2-3, (Table 8). The data also suggested CRE for 1-step clade 1-6 nested in

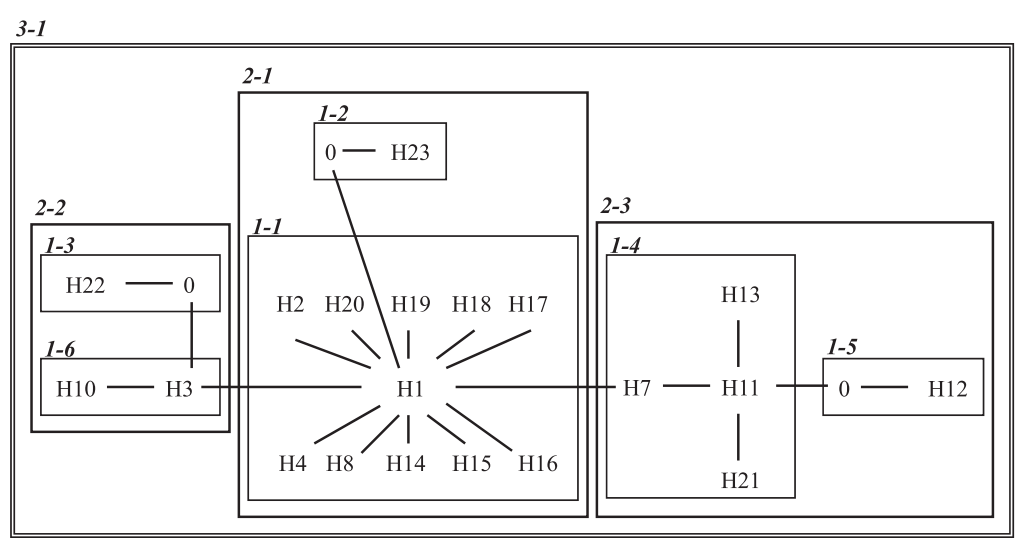

Fig. 2. The estimated $95 \%$ plausible set of cladograms and associated nested design for the ND5 haplotypes found in masu salmon. Clades are nested according to rules outlined in Templeton et al. (1995). Zeros indicate haplotype states that are necessary intermediates between observed haplotypes but that were not observed in the samples. Each solid line interconnecting two haplotype states represents a single mutational change. Narrow-lined boxes enclose one-step clades, which are designed by " $1-x$ " where $x$ is a number assigned to identify the clade; wide-lined boxes enclose two-step clades ("2-x"). Individual haplotypes are considered 0-step clades; haplotype separated by a single mutation are grouped into 1-step clades (1-1, 1-2, 1-3,1-4, 1-5, and 1-6); and 1-step clades separated by a single mutation are grouped into 2 -step clades $(2-1,2-2$, and 2-3). The last group includes all haplotype in a single 3-step clade (3-1).

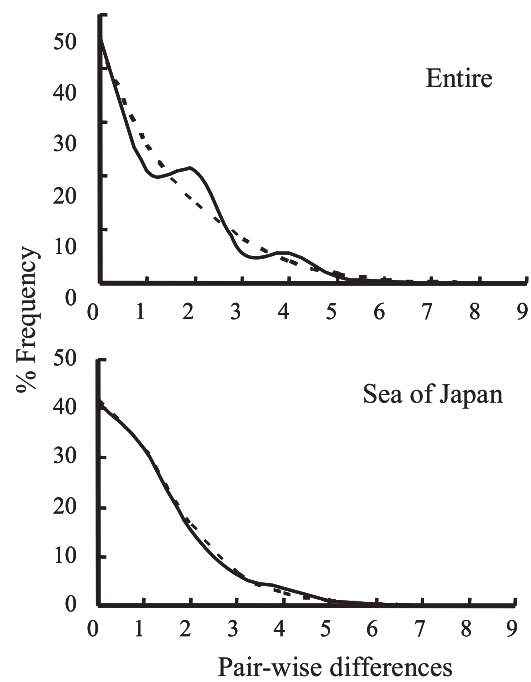

Fig. 4. Frequency distributions of pairwise nucleotide differences between haplotypes of masu salmon in the entire population and those from the Sea of Japan coasts. Solid lines, observed frequency; dashed lines, frequency distribution expected from a sudden expansion model; $S S D$, sum of squared deviations in the goodness-of-fit test. Entire population, $S S D=0.007$, $P=0.649$; Sea of Japan, $S S D=0.000, P=0.927$.

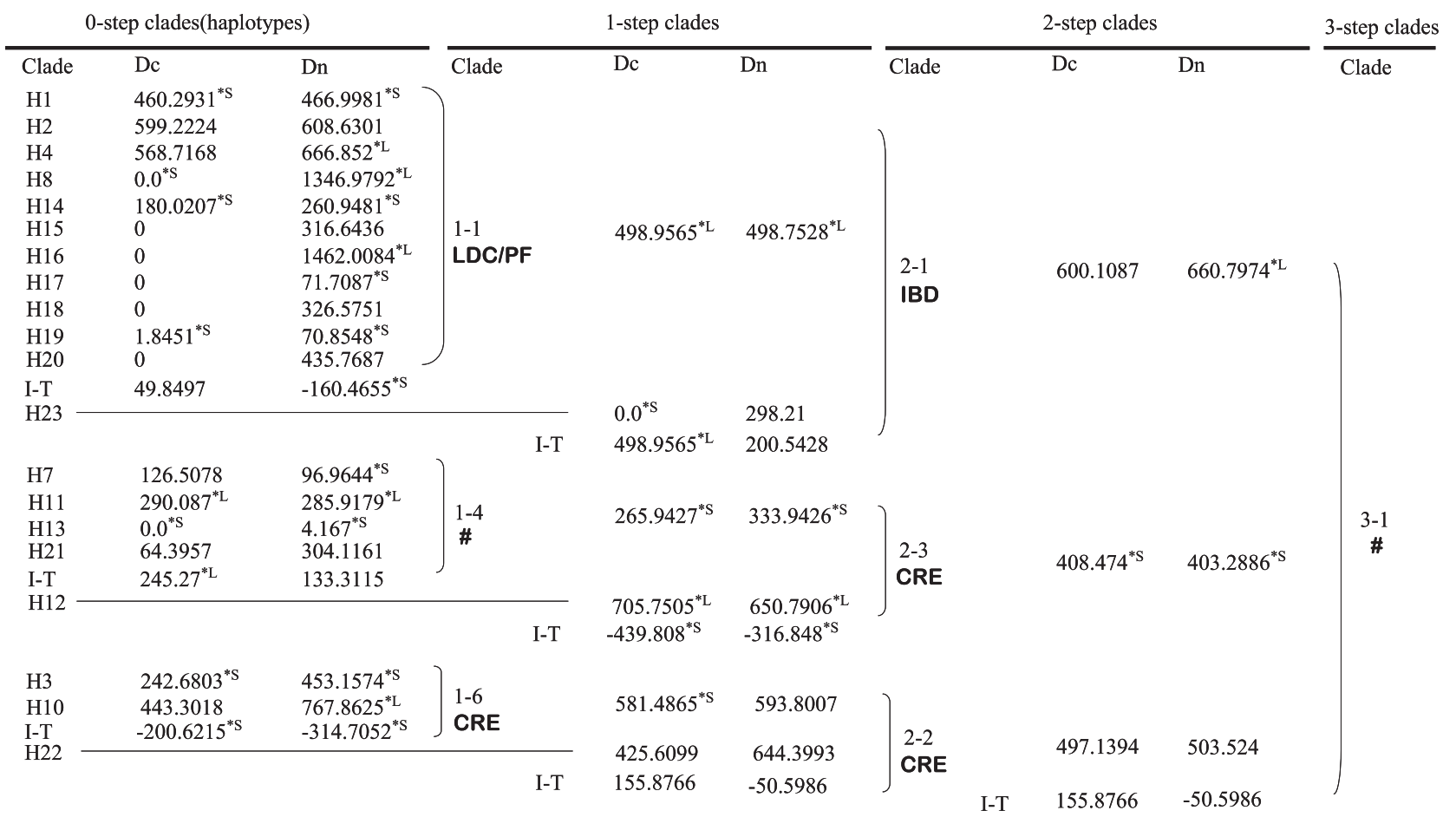

Fig. 3. Nested clade distance analysis for ND5 haplotypes observed in masu salmon. Brackets reflect the nesting structure (see Fig. 3). Dc and Dn are clade and nested clade distances, respectively (for details see Templeton et al., 1995). Interior vs tip contrasts for Dc and Dn are indicated with ' $I-T$ ' in the corresponding clade, with interior clades given in bold italic font. Superscripts ${ }^{* S}$ and ${ }^{* L}$ indicate distance measures that are significantly smaller and larger, respectively, than expected under a random distribution of haplotypes. 
clade 2-2, but for the other two 1-step clades (1-1 and 1-4), nested in clades 2-1 and 2-3, respectively, the inferences were rather ambiguous and could have been long-distance colonization and/or past fragmentation (LDC/PF) and restricted gene flow/dispersal, or past gene flow followed by extinction of intermediate populations (\# in Fig. 3). The latter ambiguous interpretation was also inferred for the entire cladogram (clade 3-1) (Table 8).

The mismatch distributions for all populations and those for the Sea of Japan coasts are shown in Fig. 4, as no other population groups were significant for Tajima's $D$, Fu's $F_{\mathrm{S}}$, and/or SSD (not shown). All populations together showed a sinuous mismatch distribution, with low to moderate peaks at 2 and 4 sequence differences, though the highest frequency was at 0 differences. The Sea of Japan populations showed no additional peaks in the distribution due to an excess of 0 and 1 nucleotide differences (Fig. 4). $D$, Fu's $F_{\mathrm{S}}$, and $S S D$ (Table 9) suggested expansion for these population groups. Either the negative $D$ or the $F \mathrm{~S}$ value was marginally or distinctly significant, with substantially small $S S D$ but higher $P$ values, in the Sea of Japan populations $\left(D=-1.402, P=0.058 ; F_{S}=-5.176, P\right.$ $=0.049 ; S S D=0.000, P=0.927)$ and all populations together $\left(D=-1.526, P=0.024 ; F_{S}=-10.285, P=0.016\right.$; $S S D=0.007, P=0.649$ ) (Table 9), favoring sudden expansion. The $\tau$ value, which reflects the location of the mismatch distribution crest, provides a rough estimate of the time when rapid population expansion started (Rogers and Harpending, 1992; Rogers, 1995). The sudden expansion of populations was estimated to have occurred $0.049-0.217$ $\mathrm{Ma}$ in the Sea of Japan populations, and 0.089-0.394 Ma for all populations (Table 9).

\section{DISCUSSION}

Our ND5 and microsatellite analyses gave congruent estimates of the population genetic structure of masu salmon in the Far East (although the extent of variance suggested by AMOVAs was always larger for ND5 than for microsatellites): (i) weak structuring among populations in Japan, Korea, and Russia, and large groups on the coasts of the Sea of Japan, Sea of Okhotsk, and Pacific; (ii) moderate structuring among coastal regions in the Sea of Japan and Sea of Okhotsk; and (iii) moderate structuring within Japan but not within Russia. The findings for Russia may be ascribed to substantial sampling gaps.

The clade topology of the ND5 haplotypes and nucleotide divergencies between or within clades in masu salmon (Fig. 2; Table 7) suggest a shallow haplotype genealogy as a whole. In particular, the lineage of haplotype $\mathrm{H} 1$ showed a clear star-like pattern, with the radiating haplotypes mostly region specific, suggesting their recent appearance and rapid expansion (Slatkin and Hudson, 1991; Rodgers and Harpending, 1992) in Japan, Korea, and Russia. This sort of shallow haplotype genealogy has also been reported in some other Pacific salmon and is probably the consequence of population decreases in glacial periods and subsequent recovery during interglacial periods (Mccusker et al., 2000; Churikov and Gharrett, 2002; Sato et al., 2004).

Six microsatellite loci developed for masu and other salmonids were highly polymorphic in all the masu populations we examined, with locus-dependent variability but without linkage disequilibrium between loci. The observed HWE, which was distributed among loci and populations due mostly to heterozygote deficits, was likely caused by null or non-amplifying alleles arising from nucleotide polymorphisms at priming sites. Beyond the hypothesis of null alleles, the heterozygote deficiency could also have been due to other factors, such as admixture of more than two independent populations, non-random mating, or artificial or natural selection during seed production and cultivation. In this study, the heterozygote deficits did not occur in all the loci and populations, which may reflect features of the masu populations examined rather than drawbacks of the microsatellite markers employed, although the exact cause remains unknown.

Incongruent population genetic structures inferred from mitochondrial and microsatellite

Table 9. Parameters of the sudden expansion model and estimated time since expansion for masu salmon, according to Rogers and Hairpending (1992),Tajima (1993), and Fu (1997). D, Tajima's D; Fs, Fu's Fs; SSD, sum of squared deviations in the goodness-of-fit test; $\tau$, time since expansion measured in mutational time units; $\mathrm{Cl}$, confidence interval; $\theta_{0}$ and $\theta_{1}$, population sizes scaled by mutation rate before and after expansion, respectively.

\begin{tabular}{|c|c|c|c|c|c|c|c|c|}
\hline Populations & Sample size & $\begin{array}{c}D \\
\text { (P-value) }\end{array}$ & $\begin{array}{c}\text { Fs } \\
\text { (P-value) }\end{array}$ & $\begin{array}{c}S S D \\
(\mathrm{P} \text {-value })\end{array}$ & $\begin{array}{c}\tau \\
(95 \% \mathrm{Cl})\end{array}$ & $\begin{array}{c}\theta_{0} \\
(95 \% \mathrm{Cl})\end{array}$ & $\begin{array}{c}\theta_{1} \\
(95 \% \mathrm{Cl})\end{array}$ & $\begin{array}{c}\text { Time since expansion } \\
\text { (year) }\end{array}$ \\
\hline \multirow[t]{2}{*}{ Entire (18) } & 895 & -1.526 & -10.285 & 0.007 & 2.214 & 0.063 & 431.372 & $89000 \sim 394000$ \\
\hline & & $(0.024)$ & $(0.016)$ & (0.649) & $(0.467 \sim 5.539)$ & $(0.000 \sim 0.087)$ & $(0.398 \sim 1743.455)$ & \\
\hline \multirow[t]{2}{*}{ Sea of Japan (7) } & 291 & -1.402 & -5.176 & 0.000 & 1.222 & 0.131 & 1283.041 & 49000 217000 \\
\hline & & $(0.058)$ & $(0.049)$ & $(0.927)$ & $(0.000 \sim 5.274)$ & $(0.000 \sim 2.213)$ & (0.167 5206.387) & \\
\hline
\end{tabular}


markers have been reported previously for other animal groups, including mammals (Nyakaana and Arctander, 1999), birds (Piertney et al., 2000; Scribner et al., 2001), and fishes (Bernatchez and Osinov, 1995; Lu et al., 2001). Some of the discordance can be explained by differences in the mode of inheritance of the two marker systems, as the effective population size for mitochondrial markers is only one quarter that of nuclear markers. In addition, some studies have found discordances larger than expected, for example, due to sex-biased gene flow among populations in mammals and insects (e.g. Nyakaana and Arctander, 1999; Doums et al., 2002). Differential mutation rates between the two markers could also result in higher accumulation of homoplasic mutations in microsatellite DNA than in mitochondrial DNA, which would contribute to a reduction in the extent of population differentiation estimated by microsatellite DNA (e.g., Viard et al., 1998). In our study, ND5 and microsatellite markers suggested different levels of gene flow as inferred by $F_{\mathrm{ST}}$ values in some pairwise comparisons (Table 5), in addition discordance in the estimated genetic diversities (see Tables 3, 4). In particular, uneven ND5 variation among the three regions (Table 3 ) might reflect the consequence of human activity, as the artificial production and release of hatchery masu salmon have long been attempted in Japan (Mayama, 1992) and Russia (Zaporozhets and Zaporozhets, 2004). However, surprisingly uniform microsatellite variation among the regions (Table 4) argues against this possibility, and the effects of artificial propagation on the observed genetic structure are unknown. The observed discrepancy in patterns of population differentiation estimated by the two markers therefore could potentially be caused by multiple factors, such as different modes of transmission and evolution of these genetic systems (Lu et al., 2001). Nevertheless, these different estimates at the population level did not seem to affect the estimation of hierarchical structure between population groups by AMOVA, providing congruent results for ND5 and microsatellites, as mentioned above.

The AMOVAs suggested the existence of large population groups on the coasts of the Sea of Japan, Sea of Okhotsk, and Pacific, in addition to the traditional grouping of masu salmon into populations in Japan, Russia, and Korea. The extent of variation in the large grouping was similar to that of the traditional grouping for both ND5 and the microsatellite markers (Analyses I and II), suggesting a similar pattern of inter-group and within-group gene flow in both cases. However, apparently larger within-group than inter-group variation is puzzling and possibly suggests low effects of geographical distance on limiting gene flow. In fact, subregional structure among coasts of the different oceans (Analyses III and IV) more clearly implies a limitation of gene flow by geographical distance, particularly with ND5, as shown by larger inter-group than within-group variation. This may also suggest different potential between the two markers for estimating genetic structure.

Our NCPA suggests that the observed genetic structure of masu salmon might have been shaped primarily by contiguous range expansion and secondarily by restricted gene flow with isolation by distance (Fig. 3; Table 8), conclusions mostly compatible with the results of AMOVA mentioned above. A low influence of isolation by distance may be related to the high homing ability of masu salmon (Okazaki 1986), which may lead to distance-independent genetic differentiation among populations by region. In fact, another Pacific salmon, chum salmon, with less accurate homing ability than masu salmon (Salo, 1991), shows clear population differentiation with isolation by distance around the Pacific Rim (Yoon et al., 2008). Besides the biological consequence, the inference from NCPA may indicate that the historical demography of masu salmon was driven by cycles of glaciation and associated sea level changes (Nürnberg and Tiedemann, 2004).

With Tajima's $D$, Fu's $F_{\mathrm{S}}, S S D$, and the mismatch distribution analysis, one or more of the parameters or estimates suggested sudden expansion of the whole population and the Sea of Japan populations (Fig. 4; Table 9) in the Late Pleistocene. In contrast, the Sea of Okhotsk populations, not fitting the sudden expansion model, likely experienced a complex demographic history, inferred from the sinuous or bimodal mismatch distribution pattern (not shown), as also seen for the entire population (Fig. 4), This may suggest that exponential population growth occurred at least twice in the past, probably associated with the movements of glaciers in the Sea of Okhotsk. Chum salmon populations are thought to have undergone dramatic reductions in size in the Sea of Okhotsk in the past, due to decreases in their ranges during glacial periods and subsequent reintroductions after the retreat of glaciers (Brykov et al., 2003). If this was also the case for masu salmon, these populations might have undergone population decreases in the Sea of Okhotsk and colonized the Sea of Japan during glacial periods (Kitanishi et al., 2007). The scenario of relatively recent, rapid population growth for masu salmon on the Sea of Japan coasts after glacial bottlenecking is favored by the star-like genealogy of haplotypes in those areas, the mismatch distribution pattern supporting the sudden expansion model, and the estimated expansion time described above. The low genetic diversity observed for the Russian populations, estimated by ND5 haplotype diversity, may also be relevenat to the probable decrease in population range in the Sea of Okhotsk during multiple glacial periods, sometime after colonization to the Sea of Japan.

In conclusion, the population genetic structure of masu salmon endemic to the Far East likely reflects demographic histories related to past glacial movements, probably in the Sea of Okhotsk. The newly detected large population groups on the coasts of the Sea of Japan, Sea of Okhotsk, and Pacific may also be primarily the consequence of this historical demography. Our population genetic data based on mitochondrial and microsatellite DNA markers will be useful in conserving and managing both the river-resident and anadromous forms of masu salmon, as rapidly decreasing commercial catches of both forms are of common urgent concern in Japan, Korea, and Russia (e.g., Kato, 1991; Augerot, 2005).

\section{ACKNOWLEDGMENTS}

This study was supported in part by Grants-in-Aid from the Fisheries Agency of Japan, the Northern Advancement Center for Science and Technology, and the 21st COE program (K-2) 'Marine Bio-Frontier for Food Production' at Hokkaido University, sponsored 
by the Ministry of Education, Culture, Sports, Science and Technology, Japan.

\section{REFERENCES}

Andersson E, Peixoto B, Tormanen V, Matsunaga T (1995) Evolution of the immunoglobulin $\mathrm{M}$ constant region genes of salmonid fish, rainbow trout (Oncorhynchus mykiss) and Arctic charr (Salvelinus alpinus): implications concerning divergence time of species. Immunogenetics 41: 312-315

Augerot X (2005) Atlas of Pacific Salmon: The First Map-Based Status Assessment of Salmon in the North Pacific. University of California Press, Berkeley, pp 88-91

Bernatchez L, Osinov A (1995) Genetic diversity of trout (genus Salmo) from its most eastern native range based on mitochondrial DNA and nuclear gene variation. Mol Ecol 4: 285-297

Brykov VIA, Polyakova NE, Prokhorova AV (2003) Phylogeographic analysis of chum salmon Oncorhynchus keta Walmaum in Asian populations based on mtDNA variation. Russ J Genet 39: 61-67

Cavalli-Sforza LL, Edwards AWF (1967) Phylogenetic analysis: models and estimation procedures. Am J Human Genet 19: 233-257

Churikov D, Gharrett AJ (2002) Comparative phylogeography of the two pink salmon broodlines: an analysis based on mitochondrial DNA. Mol Ecol 11: 1077-1101

Clement M, Posaka D, Crandall KA (2000) TCS: a computer program to estimate gene genealogies. Mol Ecol 9: 1657-1659

Davis GP, Hetzel DJS (2000) Integrating molecular genetic technology with traditional approaches for genetic improvement in aquaculture species. Aquaculture Res 31: 3-10

Doums C, Cabrera H, Peeters C (2002) Population genetic structure and male-biased dispersal in the queenless ant, Diacamma cyaneiventre. Mol Ecol 11: 2251-2264

Edpalina RR, Yoon M, Urawa S, Kusuda S, Urano A, Abe S (2004) Genetic variation in wild and hatchery populations of Masu salmon (Oncorhynchus masou) inferred from mitochondrial DNA sequence analysis. Fish Genet Breed Sci 34: 37-44

Excoffier L, Laval G, Schneider S (2005) Arlequin ver. 3.0: an integrated software package for population genetics data analysis. Evol Bioinform Online 1: 47-50

Felsenstein J (2004) PHYLIP (Phylogeny Inference Package) version 3.6. Distributed by the author. Department of Genome Sciences, University of Washington, Seattle

Ferris SD, Berg WJ (1987) The utility of mitochondrial DNA in fish genetics and fishery management. In "Population Genetics and Fishery Management" Ed by N Ryma, F Utter, University of Washington Press, Seattle, pp 277-300

Frankel OH, Soulé ME (1981) Conservation and Evolution. Cambridge University Press, Cambridge

Fu Y-X (1997) Statistical tests of neutrality of mutations against population growth, hitchhiking and background selection. Genetics 147: 915-925

Goudet J (2001) FSTAT: A Program to Estimate and Test Gene Diversities and Fixation Indices (version 2.9.3). Available from http://www.unil.ch/izea/softwares/fstat.html.

Hoffmann AA, Sgrh CM, Lawler SH (1995) Ecological population genetics: the interface between genes and the environment. Genetics 29: 349-370

Kato F (1991) Life histories of masu and amago salmon (Oncorhynchus masou and Oncorhynchus rhodurus). In "Pacific Salmon Life Histories" Ed by C Groot, L Margolis, UBC Press, Vancouver, pp 396-414

Kijima A, Matsunami D (1992) Haplotypic differences and variability of mitochondrial DNA among cultured stocks of the masu salmon complex. Nippon Suisan Gakkaishi 58: 1431-1436

Kitanish S, Edo K, Yamamoto T, Azuma N, Hasegawa O, Higashi S
(2007) Genetic structure of masu salmon (Oncorhynchus masou) populations in Hokkaido, northernmost Japan, inferred from mitochondrial DNA variation. J Fish Biol 71: 437-452

Lu G, Basley DJ, Bernatchez L (2001) Contrasting patterns of mitochondrial DNA and microsatellite introgressive hybridization between lineages of lake whitefish (Coregonus clupeaformis); relevance for speciation. Mol Ecol 10: 965-985

Mayama H (1992) Studies on the freshwater life and propagation technology of masu salmon, Oncorhynchus masou (Brevoort). Sci Rep Hokkaido Salmon Hatchery 46: 1-156

McCusker MR, Parkinson E, Taylor EB (2000) Mitochondrial DNA variation in rainbow trout (Oncorhynchus mykiss) across its native range: testing biogeographical hypotheses and their relevance to conservation. Mol Ecol 9: 2089-2108

Miyakoshi Y, Nagata M, Sugiwaka K, Kitada S (2001) Commercial harvest of hatchery-reared masu salmon Oncorhynchus masou estimated by a coast-wide sampling program in Hokkaido, northern Japan, and the two-stage sampling schemes of landings. Fish Sci 67: 126-133

Miyakoshi Y, Koyama T, Aoyama T, Sakakibara S, Kitada S (2004) Estimates of numbers of masu salmon caught by recreational fishermen in the coastal area off Iburi, Hokkaido, Japan. Fish Sci 70: 87-93

Naish KA, Park LK (2002) Linkage relationships for 35 new microsatellite loci in chinook salmon Oncorhynchus tshawytscha. Anim Genet 33: 316-318

Nei M (1987) Molecular Evolutionary Genetics. Columbia University Press, New York

Noguchi D, Taniguchi N (2007) Studies on the genetic diversity of wild populations of masu salmon, Oncorhynchus masou masou, by microsatellite DNA markers. Aquaculture Sci 55: 521-527 (in Japanese with English abstract)

Noguchi D, Ikeda M, Nakajima M, Taniguchi N (2003) Isolation and characterization of microsatellite DNA markers for population genetics study of masu salmon, Oncorhynchus masou masou. Fish Genet Breed Sci 33: 61-66 (in Japanese with English abstract)

Nürnberg D, Tiedemann R (2004) Environmental change in the Sea of Okhotsk during the last 1.1 million years. Paleoceanography 19: PA4011

Nyakaana S, Arctander P (1999) Population genetic structure of the African elephant in Uganda based on variation at mitochondrial and nuclear loci: evidence for male-biased gene flow. Mol Ecol 8: $1105-1115$

O'Connell M, Wright JM (1997) Microsatellite DNA in fishes. Rev Fish Biol Fish 7: 331-363

Okazaki T (1986) Genetic variation and population structure in masu salmon Oncorhynchus masou of Japan. Bul Japan Soc Sci Fish 52: 1365-1376

Olsen JB, Wilson SL, Kretschmer EJ, Jones KC, Seeb JE (2000) Characterization of 14 tetranucleotide microsatellite loci derived from sockeye salmon. Mol Ecol 9: 2185-2187

Oosterhout CV, Hutchinson WF, Derek P, Wills M, Shipley P (2004) MICRO-CHECKER: Software for identifying and correcting genotyping errors in microsatellite data. Mol Ecol Notes 4: 535538

Panchal M, Beaumont MA (2007) The automation and evaluation of nested clade phylogeographic analysis. Evolution 61: 14661480

Piertney SB, Summers R, Marquiss M (2000) Microsatellite and mitochondrial DNA homogeneity among phenotypically diverse crossbill taxa in the UK. Proc R Soc Lond B 268: 1511-1517

Posada D, Crandall KA, Templeton AR (2000) GeoDis: a program for the cladistic analysis of the geographical distribution of genetic haplotypes. Mol Ecol Notes 9: 487-488

Raymond M, Rousset F (2004) Genepop (version 3.4): population genetics software for exact tests and ecumenicism. Available 
at: http://genepop.curtin.edu.au/

Rogers AR, Harpending H (1992) Population growth makes waves in the distribution of pairwise genetic differences. Mol Biol Evol 9: 552-569

Salo EO (1991) Life history of chum salmon (Oncorhynchus keta). In "Pacific Salmon Life Histories" Ed by C Groot, L Margolis, UBC Press, Vancouver, pp 231-309

Sato S, Kojima H, Ando J, Wilmot RL, Seeb LW, et al. (2004) Genetic population structure of chum salmon in the Pacific Rim inferred from mitochondrial DNA sequence variation. Environ Biol Fish 69: 38-50

Schneider S, Roessli D, Excoffier L (2000) ARLEQUIN: A Software for Population Genetics Data Analysis. User Manual Ver 2.000. University of Geneva, Geneva

Scribner KT, Petersen MR, Fields RL, Talbot SL, Pearce JM, Chesser RK (2001) Sex-biased gene flow in spectacled eiders (Anatidae): inferences from molecular markers with contrasting modes of inheritance. Evolution 55: 2105-2115

Slatkin M, Hudson RR (1991) Pairwise Comparisons of Mitochondrial DNA Sequences in Stable and Exponentially Growing Populations. Genetics 129: 555-562

Suzuki K, Kobayashi T, Matsuishi T, Numachi K (2000) Genetic variability of masu salmon in Hokkaido, by restriction fragment length polymorphism analysis of mitochondrial DNA. Nippon Suisan Gakkaishi 66: 639-646 (in Japanese with English abstract)

Tajima F (1993) Measurement of DNA polymorphism. In "Mechanisms of Molecular Evolution. Introduction to Molecular Paleo- population Biology" Ed by N Takahata, AG Clark, Sinauer Associates, Sunderland, pp 37-59

Takayama Y, Rand-Weaver M, Kawauchi H, Ono M (1991) Gene structure of chum salmon somatolactin, a presumed pituitary hormone of the growth hormone/prolactin family. Mol Endocrinol 5: 778-786

Taniguchi N, Yamazaki M, Takagi M, Tsujimura A (1996) Genetic and environmental variances of body size and morphological traits in communally reared clonal lines from gynogenetic diploid ayu, Plecoglossus altivelis. Aquaculture 140: 333-341

Templeton AR, Routman E, Phillipa CA (1995) Separating population structure from population history: a cladistic analysis of the geographical distribution of mitochondrial DNA haplotypes in the tiger salamander, Ambystoma tigrinum. Genetics 140: 767-782

Viard F, Franck P, Dubois M-P, Estoup A, Jarne P (1998) Variation of microsatellite size homoplasy across electromorphs, loci, and populations in three invertebrate species. J Mol Evol 47: 42-51

Yoon M, Sato S, Seeb JE, Brykov V, Seeb LW, et al. (2008) Mitochondrial DNA variation and genetic population structure of chum salmon Oncorhynchus keta around the Pacific Rim. J Fish Bio 73: 1256-1266

Zaporozhets OM, Zaporozhets GV (2004) Interaction between hatchery and wild Pacific salmon in the Far East of Russia: a review. Rev Fish Biol Fish 14: 305-319

(Received June 30, 2009 / Accepted December 8, 2009) 